\title{
Article
}

\section{GC-MS Based Identification of the Volatile Components of Six Astragalus Species from Uzbekistan and Their Biological Activity}

\author{
Haidy A. Gad ${ }^{1,2} \oplus$, Nilufar Z. Mamadalieva ${ }^{3,4} \oplus$, Stefan Böhmdorfer ${ }^{5}\left({ }^{\oplus}\right.$, Thomas Rosenau ${ }^{5} \oplus$, Gokhan Zengin ${ }^{6}(\mathbb{C}$, \\ Rano Z. Mamadalieva ${ }^{7}$, Nawal M. Al Musayeib ${ }^{8, *}$ and Mohamed L. Ashour ${ }^{1, *(D)}$ \\ 1 Department of Pharmacognosy, Faculty of Pharmacy, Ain Shams University, Cairo 11566, Egypt; \\ haidygad@pharma.asu.edu.eg \\ 2 Department of Pharmacognosy, Faculty of Pharmacy, King Salman International University, South Sinai, \\ Ras Sidr 46612, Egypt \\ 3 Institute of the Chemistry of Plant Substances, Academy of Sciences of RUz, Mirzo Ulugbek Str. 77, \\ Tashkent 100170, Uzbekistan; nmamadalieva@yahoo.com \\ 4 Department of Bioorganic Chemistry, Leibniz Institute of Plant Biochemistry, Weinberg 3, \\ D-06120 Halle (Saale), Germany \\ 5 Department of Chemistry, Institute of Chemistry of Renewable Resources, University of Natural Resources \\ and Life Sciences, Vienna (BOKU University), Konrad-Lorenz-Straße 24, 3430 Tulln, Vienna, Austria; \\ stefan.boehmdorfer@boku.ac.at (S.B.); thomas.rosenau@boku.ac.at (T.R.) \\ 6 Biochemistry and Physiology Research Laboratory, Department of Biology, Science Faculty, Selcuk University, \\ 42130 Konya, Turkey; gokhanzengin@selcuk.edu.tr \\ 7 Kokand State Pedagogical Institute, Turon Str. 23, Kokand 713000, Uzbekistan; rmamadalieva@yahoo.com \\ 8 Department of Pharmacognosy, College of Pharmacy, King Saud University, Riyadh 11495, Saudi Arabia \\ * Correspondence: nalmusayeib@ksu.edu.sa (N.M.A.M.); ashour@pharma.asu.edu.eg (M.L.A.); \\ Tel.: +20-10-68-222-354 (M.L.A.); Fax: +20-22-405-1107 (M.L.A.)
}

Citation: Gad, H.A.; Mamadalieva, N.Z.; Böhmdorfer, S.; Rosenau, T.; Zengin, G.; Mamadalieva, R.Z.; Al Musayeib, N.M.; Ashour, M.L. GC-MS Based Identification of the Volatile Components of Six Astragalus Species from Uzbekistan and Their Biological Activity. Plants 2021, 10, 124. https://doi.org/10.3390/ plants10010124

Received: 19 December 2020 Accepted: 4 January 2021 Published: 8 January 2021

Publisher's Note: MDPI stays neutral with regard to jurisdictional clai$\mathrm{ms}$ in published maps and institutional affiliations.

Copyright: $\odot 2021$ by the authors. Licensee MDPI, Basel, Switzerland. This article is an open access article distributed under the terms and conditions of the Creative Commons Attribution (CC BY) license (https:// creativecommons.org/licenses/by/

Abstract: The compositions of volatile components in the aerial parts of six Astragalus species, namely A. campylotrichus (Aca), A. chiwensis (Ach), A. lehmannianus (Ale), A. macronyx (Ama), A. mucidus (Amu) and $A$. sieversianus (Asi), were investigated using gas chromatograph-mass spectrometry (GC-MS) analysis. Ninety-seven metabolites were identified, accounting for 73.28, 87.03, 74.38, 87.93, 85.83, and $91.39 \%$ of Aca, Ach, Ale, Ama, Amu and Asi whole oils, respectively. Sylvestrene was the most predominant component in $A s i, A m u$ and $A m a$, with highest concentration in $A s i(64.64 \%)$. In addition, (E)-2-hexenal was present in a high percentage in both Ale and Ach (9.97 and 10.1\%, respectively). GCMS based metabolites were subjected to principal component analysis (PCA) and hierarchal cluster analysis (HCA) to explore the correlations between the six species. The PCA score plot displayed clear differentiation of all Astragalus species and a high correlation between the Amu and Ama species. The antioxidant activity was evaluated in vitro using various assays, phosphomolybdenum (PM), 2,2 diphenyl-1-picryl-hydrazyl-hydrate (DPPH), 2,2-azino bis (3-ethylbenzothiazoline-6-sulphonic acid) (ABTS), cupric reducing antioxidant capacity (CUPRAC), ferric reducing power (FRAP) and ferrous ion chelation (FIC) assays. In addition, the potential for the volatile samples to inhibit both acetyl/butyrylcholinesterases (AChE, BChE), $\alpha$ - amylase, $\alpha$-glucosidase and tyrosinase was assessed. Most of the species showed considerable antioxidant potential in the performed assays. In the DPPH assay, Ama exhibited the maximum activity $(24.12 \pm 2.24 \mathrm{mg} \mathrm{TE} / \mathrm{g}$ sample), and the volatiles from Amu exhibited the highest activity ( $91.54 \mathrm{mgTE} / \mathrm{g}$ oil) in the ABTS radical scavenging assay. The effect was more evident in both CUPRAC and FRAP assays, where both Ale and Ama showed the strongest activity in comparison with the other tested species $(84.06,80.28 \mathrm{mgTE} / \mathrm{g}$ oil for CUPRAC and 49.47, $49.02 \mathrm{mgTE} / \mathrm{g}$ oil for FRAP, respectively). Asi demonstrated the strongest AChE (4.55 mg GALAE/g oil) and BChE (3.61 mg GALAE/g oil) inhibitory effect. Furthermore, the best tyrosinase inhibitory potential was observed for Ale (138.42 mg KAE/g). Accordingly, Astragalus species can be utilized as promising natural sources for many medicinally important components that could be tested as drug candidates for treating illnesses such as Alzheimer's disease, diabetes mellitus and oxidative stress-related diseases. 
Keywords: leguminosae; Astragalus; chemometrics; GC-MS; volatile components; antioxidants; enzyme inhibition

\section{Introduction}

Astragalus (family Leguminosae) is a large genus widely distributed in the temperate regions of the world, principally in Eurasia and North America. This genus is notable because of its worldwide taxonomic problems. Therefore, it represents an endless mine for taxonomists' work that results in constant revision, particularly at the section level. Astragalus is a characteristic Irano-Turanian region genus, and many of its species show a narrow geographic range (narrow endemics), which makes them vulnerable to extinction. Most members of this genus are generally associated with semi-arid and arid habitats across the world [1]. There are about 650 species of Astragalus in the flora of Central Asia, while nearly 275 species are among the Uzbek flora [2].

Many Astragalus species have been used for centuries in the traditional medicine of Iran, Pakistan, India, China, and Korea. They have contributed in curing many illnesses, such as liver and kidney associated diseases, gastrointestinal disorders, and many others [1]. However, the most fame for many Astragalus species was gained owing to their potential to produce gum tragacanth, which has a number of well documented medicinal uses. In addition, it is an important substance in both the food and pharmaceutical industries [1].

Among these species, the roots of Astragalus membranaceus Bge. var. mongholicus (Bge.) Hsiao and A. membranaceus (Fisch.) Bge. along with their products are documented in the Chinese Pharmacopeia for the treatment of many syndromes associated with "qi deficiency". On the other hand, in traditional Uzbek medicine, the decoction obtained from the fruits of $A$. sieversianus is used to remove kidney and bladder stones. Meanwhile, the ingested seeds are used to improve hernias in kids and are smoked to treat syphilis [2]. Leaves and gummy exudates of $A$. rubrivenosus Gontsch and A. abolinii Popov are considered useful in the treatment of kidney disease, hypertonic disease, and in burns as a demulcent [1].

Some members of Astragalus are well known for their pharmacological properties. It was reported that many species and their isolated components possessed promising anti-inflammatory, immunostimulant, antioxidant, anti-cancer, antidiabetic, hepatoprotective, cardioprotective, antibacterial, and antiviral activities [3]. Phytochemical and biological investigations of Astragalus have resulted in the isolation and identification of triterpenoid and steroidal saponins, flavonoids, phenylpropanoids, alkaloids, and some other compounds. About 260 secondary metabolites were isolated from the genus. They represent a very good source for drug discovery since most of the isolated saponins are found only in this genus, offering excellent lead drugs [4]. Astragalosides are the most widely studied secondary metabolites isolated from Astragalus, which support the integrity of the respiratory tract [5]. Astragaloside IV is the most widely known saponin due to its high biological potential as an antioxidant, antiaging, anti-inflammatory, antidiabetic, and antiatherosclerosis agent, in addition to being active against hepatitis virus B. Furthermore, polysaccharides isolated from many Astragalus species have a markedly positive effect on supporting the deep immune function by restoring the normal levels and functions of many immune cells, especially when the immune system is stressed by either environmental or endogenous challenges [6].

The aim of this study was to investigate the chemical composition of the volatile components obtained from the aerial parts of six species of Astragalus, namely, A. sieversianus Pall (Asi), A. campylotrichus Bunge (Aca), A. lehmannianus Bunge (Ale), A. macronyx Bunge (Ama), A. mucidus Bunge (Amu), and A. chiwensis Bunge (Ach) (Figure 1) grown in Uzbekistan, based on GC-MS analyses. Moreover, the metabolites' differences between the species were explored by applying multivariate analyses based on the GC-MS analyses. In 
addition, the volatile extracts were assessed for their antioxidant and enzyme inhibitory activities.
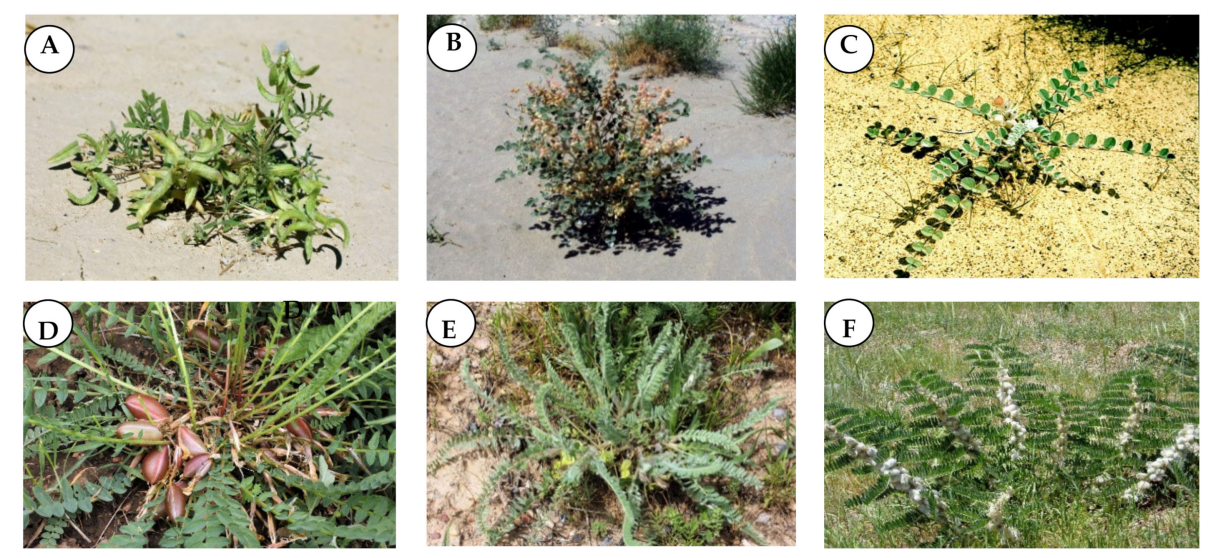

Figure 1. Photographs of some Astragalus species from Uzbekistan Flora (A): A. campylotrichus Bunge, (B): A. chiwensis Bunge, (C): A. lehmannianus Bunge, (D): A. macronyx Bunge, (E): A. mucidus Bunge, (F): A. sieversianus Pall (Photos: Alim Gaziev).

\section{Results and Discussion}

\subsection{Chemical Composition of Volatile Compounds}

The volatile compounds obtained from the aerial parts of different Astragalus species were analyzed both qualitatively and semi-quantitatively by GC-MS. All volatile component mixtures were yellow in color with a characteristic odor. GC analyses of the essential oils revealed the presence of 105 metabolites (Table 1), which represented 73.28, 87.03, $74.38,87.93,85.83$, and $91.39 \%$ of all Aca, Ach, Ale, Ama, Amu, and Asi volatile components, respectively.

The essential oils of different Astragalus species showed wide metabolic variation both qualitatively and quantitatively. Monoterpene hydrocarbons represented the major class solely in $A$. sieversianus (Asi), accounting for $68.47 \%$ of the total oil composition. On the contrary, monoterpene hydrocarbons were completely absent in A. campylotrichus (Aca). No oxygenated sesquiterpenes were detected in any species.

Sylvestrene was the major compound identified in Asi, Amu and Ama, with the highest concentration in Asi (64.64\%), followed by Amu (14.14\%) and Ama (10.63\%). In Ale, (E)2-hexenal $(9.97 \%)$, sylvestrene $(5.56 \%)$ and benzaldehyde $(5.54 \%)$ represented the major identified components. n-Hexadecanoic acid (8.58\%), phytol (7.49\%) and 1-octen-3-ol (6.98\%) were the main compounds detected in Aca. In Ach, (E)-2-hexenal (10.1\%), butyl hexadecanoate ester $(7.21 \%)$, trans-linalool oxide $(6.81 \%)$ and butyl hexanoate $(6.76 \%)$ were the predominant compounds. n-Hexadecanoic acid, trans- $\beta$-ionone, nonanal and benzaldehyde were detected in all Astragalus species, with the highest percentage in Ach for n-hexadecanoic acid and trans- $\beta$-ionone accounting for $8.58 \%$ and $3.34 \%$ of the whole essential oils, respectively. Ama and Ale contained the maximum amounts of nonanal $(4.71 \%)$ and benzaldehyde $(5.54 \%)$, respectively.

Many researchers have reported the essential oil compositions of various Astragalus species [7-19]. In almost all species, including our species of interest, the monoterpenes $\alpha$-terpineol, its isomer 4-terpineol, $\gamma$-terpineol along with camphor, 1,8 -cineole, $\alpha$-pinene, and bornyl acetate are the most abundant monoterpenes. Additionally, other fatty acid components, such as hexadecanoic acid and its esters, are quite common in all the characterized species. These key components might be used as markers to confirm the identity of Astragalus species. 
Table 1. Chemical composition of volatile compounds in the aerial parts of Astragalus campylotrichus (Aca), A. chiwensis (Ach), A. lehmannianus (Ale), A. macronyx (Ama), A. mucidus (Amu) and A. sieversianus (Asi).

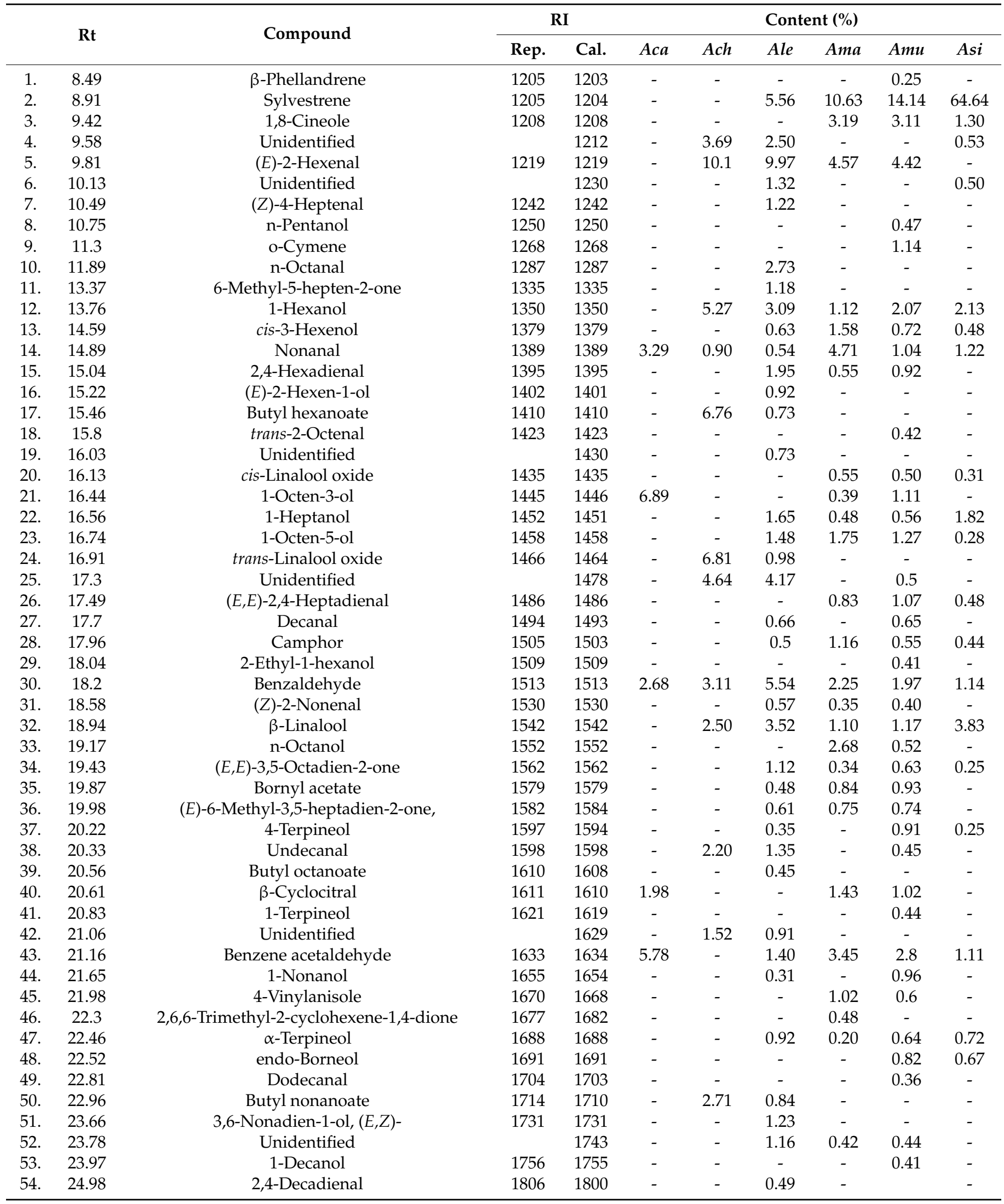


Table 1. Cont.

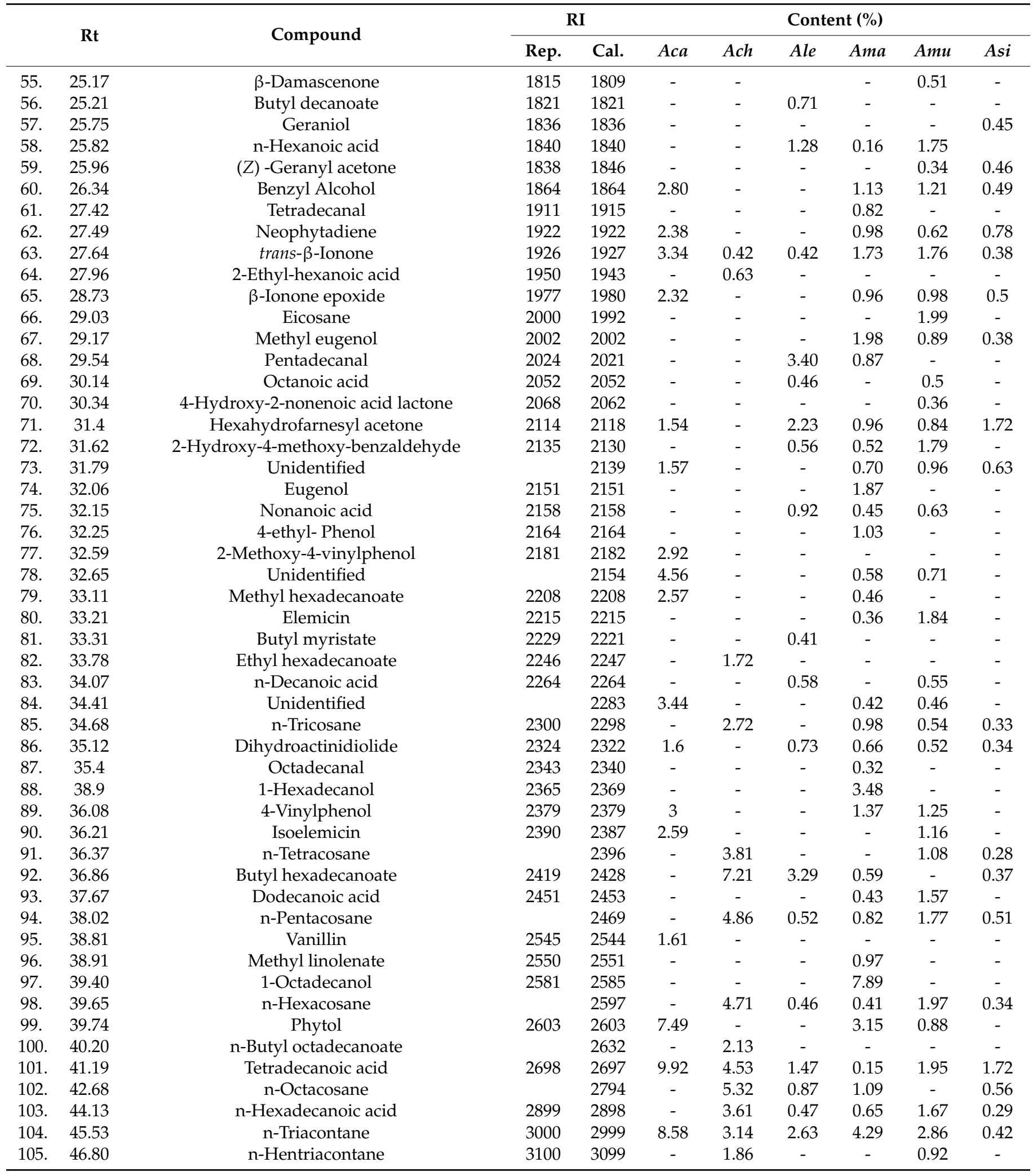


Table 1. Cont.

\begin{tabular}{|c|c|c|c|c|c|c|c|c|c|}
\hline \multirow{2}{*}{ Rt } & \multirow{2}{*}{ Compound } & \multicolumn{2}{|c|}{ RI } & \multicolumn{6}{|c|}{ Content (\%) } \\
\hline & & Rep. & Cal. & Aca & Ach & Ale & $A m a$ & $A m u$ & Asi \\
\hline & Total & & & 82.85 & 96.88 & 85.17 & 90.05 & 88.9 & 93.05 \\
\hline & Monoterpene hydrocarbons & & & - & 2.50 & 9.08 & 11.73 & 15.56 & 68.47 \\
\hline & Oxygenated monoterpene & & & 11.83 & 7.23 & 4.38 & 14.93 & 18.06 & 6.20 \\
\hline & Sesquiterpene hydrocarbons & & & 1.54 & - & 2.23 & 0.96 & 0.84 & 1.72 \\
\hline & Oxygenated sesquiterpene & & & - & - & - & - & - & - \\
\hline & Alcohols & & & 12.49 & 5.27 & 12.04 & 22.90 & 8.62 & 2.38 \\
\hline & Aldehydes and ketones & & & 15.61 & 16.31 & 30.56 & 20.81 & 11.38 & 5.20 \\
\hline & Fatty acids and their esters & & & 13.36 & 29.30 & 11.61 & 3.86 & 17.60 & 4.20 \\
\hline & Others & & & 69.48 & 87.15 & 69.48 & 62.43 & 53.90 & 16.66 \\
\hline
\end{tabular}

Compounds were identified based on the compounds' mass spectrometric data and retention indices in comparison with those of the National Institute of Standards and Technology (NIST) Mass Spectral Library (December 2011), the Wiley Registry of Mass Spectral Data, 8th edition. The content (\%) was calculated using the normalization method.

Our results are in accordance with previous work on A. microcephalis, which showed the presence of hexadecanoic acid, heneicosane, $\alpha$-cadinene, and tridecanol as the major components [7]. In addition, the essential oils from dried aerial parts of $A$. sericans and $A$. oocephalus subsp. stachyophorus revealed $\alpha$-pinene as the major component in $A$. sericans, whereas camphor, $\gamma$-terpineol, 1,8 -cineole, and $\alpha$-pinene were the major identified components of $A$. oocephalus subsp. stachyophorus, with their percentages being comparable to those in our oils.

\subsection{Chemometric Analysis Based on GC-MS}

In general, chemometric analysis together with chromatographic techniques provide a successful tool for discrimination between closely related species [20,21]. In this study, both principal component analysis (PCA) and hierarchal cluster analysis (HCA) were applied to the relative peak areas of all identified compounds of different Astragalus species to find out the relationships between different Astragalus species and explore the similarities and differences between them. The PCA score plot and correlation-loading plot are shown in Figure 2a,b, respectively. In the PCA score plot, the impact percentage of the first two principal components covered $93 \%$ of the variance in the data. Different Astragalus species could be divided into four main groups. Asi was positioned rather remotely in the plot, highlighting an obvious dissimilarity from all other species. The closeness of Ama and Amu was evident, which fell in the same quadrant with $A c a$, but obviously segregated. Ale and Ach were grouped together in a quadrant, but rather distant from each other. In-depth inspection of the correlation-loading plot (Figure $2 b$ ) revealed the correlation between sylvestrene and geraniol, accounting for the complete separation of Asi, far away from the other Astragalus species. n-Triacontane and benzaldehyde were the key compounds accountable for the segregation of Aca and Ale. Regarding Ach, a strong relationship between $(E)$-2-hexenal, butyl hexadecanoate, and undecanal was observed, accounting for its separation from other Astragalus species. These results are presented in enlarged scale Figure S1 in the Supplementary Data. 

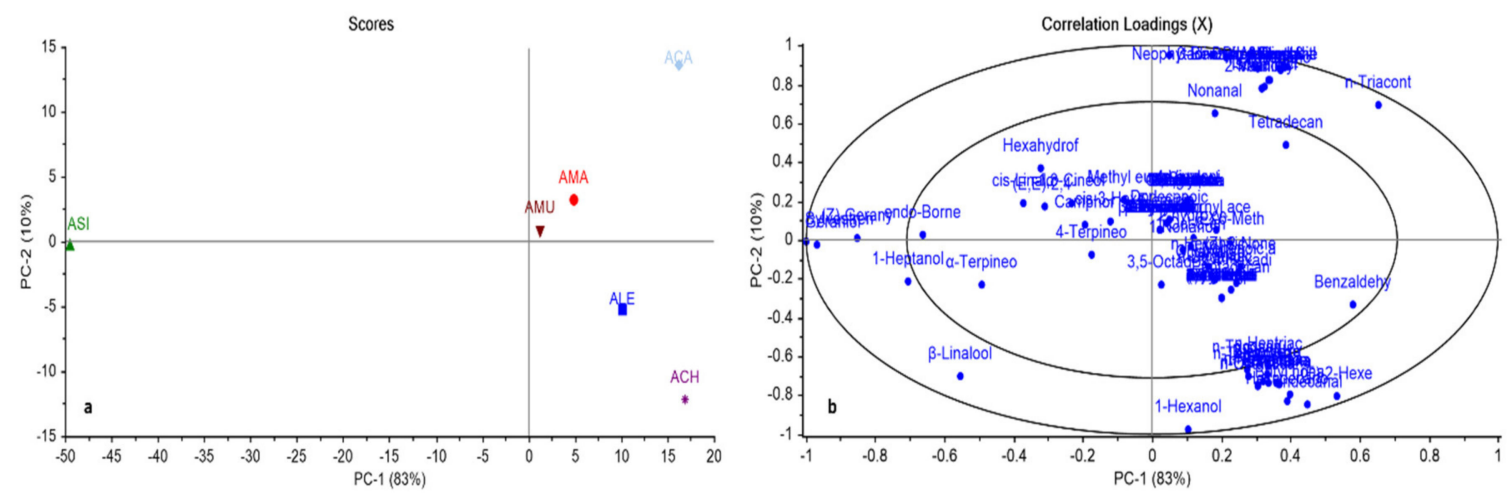

Figure 2. Principal component analysis score plot (a), correlation-loading plot (b) of GC-MS analysis of essential oils of different Astragalus species based on the identification of compounds shown in Table 1.

The HCA dendrogram (Figure 3) categorized the Astragalus species into five main clusters. Cluster I, II and III displayed Asi, Ach and Aca, respectively. Ale was positioned in a separate cluster (IV), in close distance to Aca. Cluster V was subdivided into two sub-clusters of $A m u$ and $A m a$, confirming the results from PCA.

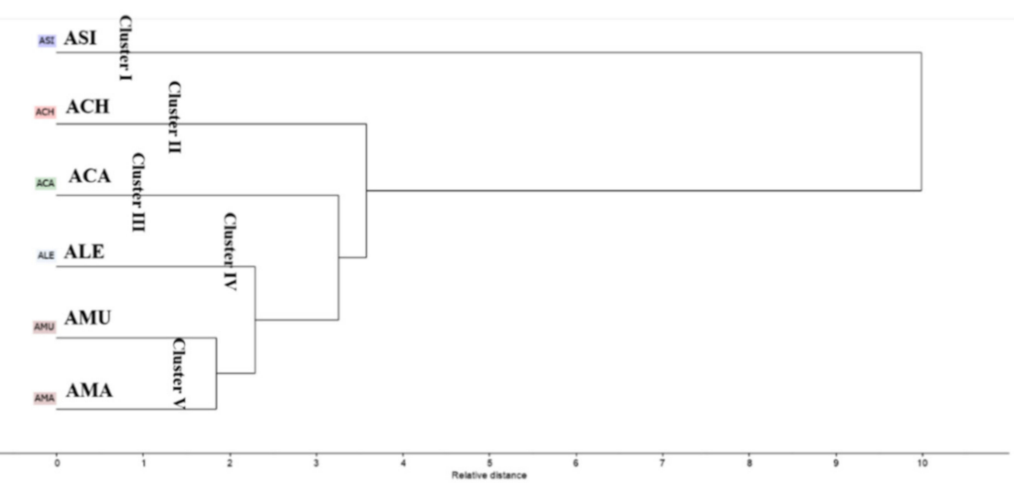

Figure 3. Hierarchical cluster analysis of the volatile components present in different Astragalus species based on the identification of compounds by GC-MS shown in Table 1.

In addition, a heat map (Figure 4) was employed to demonstrate the distribution of all the data and to portray the relative intensities of the various metabolites throughout different species, which provides immediate visualization of information for easier understanding of the complexity of data. The colors indicate the relative content of each identified metabolite among the different species, as determined by the average peak response area by GC-MS.

This is the first report of a comparison of the chemical profiles of the volatile components present in the six species studied. No information regarding the classification of the Astragalus species in Uzbekistan has been available so far; therefore, this study could be used as the basis of future chemotaxonomical work. 


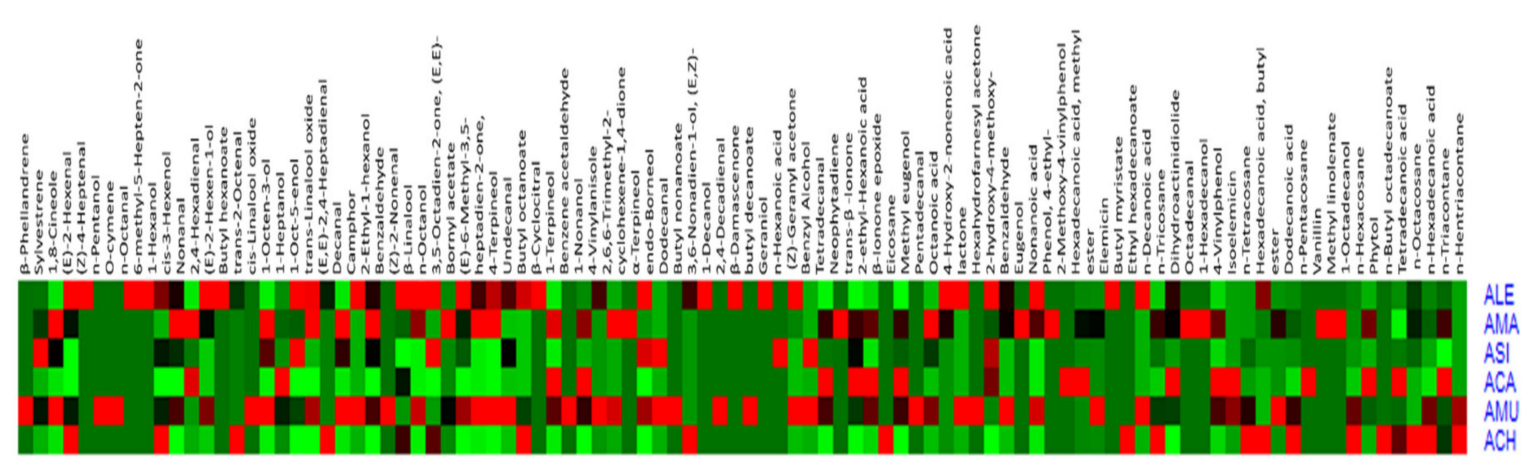

Figure 4. Heat map portraying the relative intensities of the various metabolites throughout different Astragalus species.

\subsection{Antioxidant Activity of Astragalus Species}

The antioxidant potential of the essential oil samples was performed in vitro according to various assays, comprising phosphomolybdenum (PM), ferrous ion chelating (FIC), 2,2-diphenyl-1-picryl-hydrazyl-hydrate (DPPH), 2,2-azino bis (3-ethylbenzothiazoline-6sulphonic acid) (ABTS) radical scavenging, cupric reducing antioxidant capacity (CUPRAC), and ferric reducing power (FRAP) assays.

The results displayed in Table 2 revealed that most of the samples showed considerable antioxidant potential in the assays. A. mucidus displayed the highest antioxidant activity (1.57 $\pm 0.08 \mathrm{mmol} \mathrm{TE} / \mathrm{g}$ sample) in the PM assay followed by A. lehmannianus (1.31 $\pm 0.12 \mathrm{mmol} \mathrm{TE} / \mathrm{g}$ sample), although without a statistically significant difference $(p>0.05)$. Regarding the DPPH assay, A. macrony $x$ exhibited the maximum activity ( $24.12 \pm 2.24 \mathrm{mg}$ TE/g sample), followed by A. lehmannianus ( $21.90 \pm 0.76 \mathrm{mg}$ TE/g sample). A. mucidus (91.54 $\pm 1 \mathrm{mg} \mathrm{TE} / \mathrm{g}$ sample) showed the highest antioxidant potential followed by A. macronyx ( $82.65 \pm 4.94 \mathrm{mg}$ TE/g sample) in the ABTS assay. Concerning the CUPRAC and FRAP assays, A. lehmannianus revealed the best activity, equivalent to $84.06 \pm 0.57 \mathrm{mg} \mathrm{TE} / \mathrm{g}$ oil and $49.47 \pm 0.13 \mathrm{mg}$ TE/g oil, respectively, followed by $A$. macronyx, which showed antioxidant potential of $80.28 \pm 2.65 \mathrm{mg} \mathrm{TE} / \mathrm{g}$ oil and $49.02 \pm 2.32 \mathrm{mg}$ TE/g oil. A. campylotrichus exhibited the most significant antioxidant power in the ferrous ion chelating assay (FIC, $51.69 \pm 5.94 \mathrm{mg}$ EDTAE/g sample), followed by $A$. macronyx ( $38.00 \pm 0.88 \mathrm{mg}$ EDTAE/g sample). Thus, it can be concluded that the essential oils from both A. lehmannianus and A. macronyx displayed the most significant antioxidant properties, as demonstrated by their prominent activities in most of the performed antioxidant assays. A. chiwensis exhibited moderate antioxidant activity in all reported assays.

Only a few studies have been found regarding the antioxidant properties of essential oils from Astragalus species, and most work has been carried out using the DPPH assay only. Ghahari et al (2018) determined the antioxidant properties of essential oil from A. alopecurus and found a significant DPPH radical scavenging ability ( $\mathrm{IC}_{50}$ value: $146.59 \mu \mathrm{g} / \mathrm{mL}$ ) [22]. In another study, the antioxidant abilities of two Astragalus (A. oocephalus subsp. stachyophorus and $A$. sericans) essential oils were investigated by lipid peroxidation, DPPH and reducing power assays. In the DPPH assay, the scavenging abilities were reported to be 134.22 and $44.43 \mu \mathrm{g} / \mathrm{mL}$, respectively. In our study, we preferred to use the standard equivalent way for evaluating the antioxidant properties, rendering comparison with earlier studies difficult. However, the present results obviously represented the most comprehensive antioxidant profiling of the samples available so far. 
Table 2. Antioxidant activities of the volatile extracts of Astragalus species according to the phosphomolybdenum (PM), 2,2-diphenyl-1-picryl-hydrazyl-hydrate (DPPH), 2,2-azino bis (3-ethylbenzothiazoline-6-sulphonic acid) (ABTS), cupric reducing antioxidant capacity (CUPRAC), ferric reducing power (FRAP), and ferrous ion chelating (FIC) assays.

\begin{tabular}{|c|c|c|c|c|c|c|}
\hline Samples & $\begin{array}{c}\text { PM } \\
(\mathrm{mmol} \mathrm{TE} / \mathrm{g} \text { Oil) }\end{array}$ & $\begin{array}{c}\text { DPPH } \\
\text { (mg TE/g Oil) }\end{array}$ & $\begin{array}{c}\text { ABTS } \\
\text { (mg TE/g Oil) }\end{array}$ & $\begin{array}{c}\text { CUPRAC } \\
\text { (mg TE/g Oil) }\end{array}$ & $\begin{array}{c}\text { FRAP } \\
\text { (mg TE/g Oil) }\end{array}$ & $\begin{array}{c}\text { FIC } \\
\text { (mg EDTAE/g Oil) }\end{array}$ \\
\hline A. sieversianus & $0.85 \pm 0.09^{b}$ & $9.11 \pm 0.33^{d}$ & $51.66 \pm 2.42^{\mathrm{e}}$ & $56.80 \pm 0.25^{c}$ & $30.65 \pm 2.08^{c}$ & $36.01 \pm 0.46^{b}$ \\
\hline A. mucidus & $1.57 \pm 0.08^{a}$ & $15.95 \pm 0.25^{c}$ & $91.54 \pm 1.97^{\mathrm{a}}$ & $72.46 \pm 2.29^{b}$ & $38.11 \pm 1.19^{b}$ & $18.11 \pm 0.22^{c}$ \\
\hline A. macronyx & $0.95 \pm 0.04^{b}$ & $24.12 \pm 2.24^{\mathrm{a}}$ & $82.65 \pm 4.94^{b}$ & $80.28 \pm 2.65^{a}$ & $49.02 \pm 2.32^{\mathrm{a}}$ & $38.00 \pm 0.88^{b}$ \\
\hline A. lehmannianus & $1.31 \pm 0.12^{\mathrm{a}}$ & $21.90 \pm 0.76^{\mathrm{ab}}$ & $69.58 \pm 5.04^{c}$ & $84.06 \pm 0.57^{\mathrm{a}}$ & $49.47 \pm 0.13^{\mathrm{a}}$ & $4.03 \pm 0.41^{\mathrm{d}}$ \\
\hline A. chiwensis & $0.97 \pm 0.17^{b}$ & $18.62 \pm 1.36^{b c}$ & $57.84 \pm 0.15^{\mathrm{de}}$ & $70.73 \pm 2.22^{b}$ & $39.03 \pm 1.63^{b}$ & $11.74 \pm 0.97^{c}$ \\
\hline A. campylotrichus & $0.81 \pm 0.07^{b}$ & $15.19 \pm 1.53^{c}$ & $64.61 \pm 1.74^{\mathrm{cd}}$ & $67.78 \pm 0.83^{b}$ & $39.27 \pm 0.75^{b}$ & $51.69 \pm 5.94^{\mathrm{a}}$ \\
\hline
\end{tabular}

Values expressed as means \pm S.D. of three parallel measurements. TE: Trolox equivalent; EDTAE: EDTA equivalent. Superscripts within a column indicate significant differences in Astragalus species $(p<0.05)$.

\subsection{Enzyme Inhibitory Activity of Astragalus Species}

The enzyme inhibitory properties of the Astragalus essential oils were investigated against some enzymes, including acetylcholinesterase (AChE), butyrylcholinesterase (BChE), tyrosinase, amylase, and glucosidase. The results are shown in Table 3. The highest AChE inhibitory ability was provided by A. sieversianus with $4.55 \mathrm{mg}$ GALAE/g oil, followed by $A$. chiwensis (4.52 mg GALAE/g oil), and A. lehmannianus (4.51 mg GALAE/g oil). No differences were observed for the AChE inhibitory abilities of three Astragalus species $(p>0.05)$. The lowest activity was obtained for A. macronyx in the AChE inhibition assay (4.01 mg GALAE/g oil). The BChE inhibition ability can be ordered as follows: A. sierversinaus $>$ A. mucidus $>$ A. lehmannianus $>$ A. chiewensis $>A$. macronyx. Observed cholinesterase inhibitory activities could be attributed to the presence of some volatile compounds, including monoterpenes. This was also supported by several studies, which reported significant anticholinesterase abilities of several monoterpenes [23-26]. The strongest tyrosinase inhibition ability was determined for A. lehmannianus (138.42 mg KAE/g oil) and A. macronyx (132.14 $\mathrm{mg} \mathrm{KAE/g} \mathrm{oil).} \mathrm{In} \mathrm{contrast} \mathrm{to} \mathrm{cholinesterase} \mathrm{inhibition,} \mathrm{the} \mathrm{weakest} \mathrm{tyrosinase}$ inhibitory effect was recorded for $A$. sieversianus (118.20 mg KAE/g oil). The amylase inhibition abilities ranged from $0.76 \mathrm{mmol}$ to $0.95 \mathrm{mmol} \mathrm{ACAE} / \mathrm{g}$ oil in the following order: A. chiwensis $<$ A. sieversianus $<$ A. campylotrichus $<A$. macronyx $<$ A. mucidus $<A$. lehmannianus. None of the tested essential oils were active against glucosidase.

Table 3. Enzyme inhibitory effects of the volatile extracts of Astragalus species.

\begin{tabular}{ccccc}
\hline Samples & $\begin{array}{c}\text { AChE Inhibition } \\
\text { (mg GALAE/g Oil) }\end{array}$ & $\begin{array}{c}\text { BChE Inhibition (mg } \\
\text { GALAE/g Oil) }\end{array}$ & $\begin{array}{c}\text { Tyrosinase Inhibition } \\
\text { (mg KAE/g Oil) }\end{array}$ & $\begin{array}{c}\text { Amylase Inhibition } \\
\text { (mmol ACAE/g Oil) }\end{array}$ \\
\hline A. sieversianus & $4.55 \pm 0.09^{\mathrm{a}}$ & $3.61 \pm 0.33^{\mathrm{a}}$ & $118.20 \pm 3.53^{\mathrm{d}}$ & $0.84 \pm 0.04^{\mathrm{a}, \mathrm{b}}$ \\
A. mucidus & $4.48 \pm 0.04^{\mathrm{a}}$ & $3.61 \pm 0.33^{\mathrm{a}}$ & $124.75 \pm 1.23^{\mathrm{c}}$ & $0.90 \pm 0.02^{\mathrm{a}}$ \\
A. macronyx & $4.01 \pm 0.13^{\mathrm{b}}$ & $1.04 \pm 0.09^{\mathrm{d}}$ & $132.14 \pm 0.81^{\mathrm{b}}$ & $0.89 \pm 0.04^{\mathrm{a}, \mathrm{b}}$ \\
A. lehmannianus $_{\text {A. chiwensis }}$ & $4.51 \pm 0.07^{\mathrm{a}}$ & $3.12 \pm 0.36^{\mathrm{a}, \mathrm{b}}$ & $138.42 \pm 0.66^{\mathrm{a}}$ & $0.95 \pm 0.09^{\mathrm{a}}$ \\
A. campylotrichus & $4.52 \pm 0.07^{\mathrm{a}}$ & $2.79 \pm 0.25^{\mathrm{b}, \mathrm{c}}$ & $132.79 \pm 1.04^{\mathrm{b}}$ & $0.76 \pm 0.04^{\mathrm{b}}$ \\
\hline
\end{tabular}

Values expressed as means \pm S.D. of three parallel measurements. GALAE: Galanthamine equivalent; KAE: Kojic acid equivalent; ACAE: Acarbose equivalent. Superscripts within a column indicate significant difference in Astragalus species $(p<0.05)$.

To the best of our knowledge, no reports regarding the enzyme inhibition of Astragalus essential oils were available, only some studies on the enzyme inhibitory effects of extracts from the members of Astragalus [27-29]. The presented results could open new windows for potential medical applications of the members of Astragalus. Comparing our present results with those for Ferula essential oils, it was seen that the latter showed superior activity [30].

The biological effects of the Astragalus volatile components as enzymes inhibitors may be attributed to a high percentage of oxygenated compounds, such as alcohols, acids, 
aldehydes and ketones, which can bind non-selectively to amino and sulfhydryl groups of enzymes and cause a conformational change and, thus, loss of activity.

\section{Materials and Methods}

\subsection{Plant Materials}

Aerial parts of Astragalus campylotrichus Bunge (GN0555047), A. macronyx Bunge (GN0555205), A. mucidus Bunge (GN0555131), and A. sieversianus Pall. (GN0555089) were collected from the Tashkent region (Uzbekistan, in July 2015). A. chiwensis Bunge (N20160375) and A. lehmannianus Bunge (N20160328) were collected from the Karakalpak and Bukhara regions (Uzbekistan, in June 2016). The plants were identified by Dr. Orzimat Turginov at the Laboratory of Flora of Uzbekistan, and the voucher samples have been deposited at the Herbarium of the Botany Institute, Academy of Sciences of Uzbekistan.

\subsection{Essential Oil Isolation}

The plant samples were air-dried at a temperature not exceeding $30{ }^{\circ} \mathrm{C}$ and then powdered before use. Preparation of the volatile samples of the powdered Astragalus was performed by hydro-distillation for $2 \mathrm{~h}$ using a Clevenger-type apparatus. The oil samples were maintained at $-30{ }^{\circ} \mathrm{C}$ in dark brown and air-tight, closed vials until their analyses.

\subsection{GC-MS Analysis}

GC-MS characterization of volatile components was performed on an Agilent 7890 B gas chromatograph (Agilent Technologies, Rotterdam, The Netherlands) equipped with a VF-Wax CP 9205 fused silica column (100\% polyethylene glycol, $30 \mathrm{~m} \times 0.25 \mathrm{~mm}$, $0.25 \mu \mathrm{m}$ ). It was coupled with a mass selective detector 5977A (Agilent Technologies). The instrumental settings and the separation conditions were as previously reported [31].

\subsection{Chemometric Analysis}

The data obtained from GC-MS were subjected to multivariate analysis. Principal component analysis (PCA) was performed as the first step in data analysis to provide an overview of all observations and samples and to identify and evaluate groupings, trends and strong outliers. Hierarchal cluster analysis (HCA) was used to allow clustering of samples. The clustering patterns were constructed by applying the complete linkage method. This presentation is more efficient when the distance between samples (points) is computed by the Euclidean method. Both PCA and HCA were achieved by utilizing Unscrambler®X 10.4 from CAMO (Computer Aided Modeling, Viken, AS, Norway) [20,32]. The heat map was constructed using Hierarchical Clustering Explorer 3.5 software (Humancomputer interaction laboratory, University of Maryland, College Park, MD, USA).

\subsection{Antioxidant and Enzyme Inhibitory Assays}

Different protocols were performed to explain the antioxidant properties of the tested Astragalus oils. The protocols included reducing power (CUPRAC and FRAP), metal chelating, phosphomolybenum and free radical scavenging (DPPH and ABTS). Experimental details were as previously reported $[33,34]$. The same applies for inhibitory effects of the Astragalus oils tested against different enzymes (tyrosinase, amylase, glucosidase and cholinesterase) [33,35]. Both antioxidant and enzyme inhibition assays were explained by standard equivalents (trolox and EDTA for antioxidant; galantamine for cholinesterase; kojic acid for tyrosinase; acarbose for amylase and glucosidase activity). All samples were analyzed in triplicate in three independent experiments. The experimental details are given in the Supplementary Materials.

\subsection{Statistical Analysis}

Statistical analyses were performed using ANOVA experiment (with Tukey's test, significant value: $p<0.05$ ) and Xlstat 2017 software. 


\section{Conclusions}

The volatile components identified from the aerial parts of six different Astragalus species revealed a significant variation between the species, as determined by GC-MS, which was confirmed by multivariate analysis. The essential oils showed relevant antioxidant as well as enzyme inhibitory activities. This study provides the first report about the biological activities of the studied species. Astragalus species can be utilized as promising natural sources for many medicinally important components, which could be used for drug development to address illnesses such as Alzheimer's disease, diabetes mellitus and oxidative stress related diseases. Further studies are needed to test the in vivo activities.

Supplementary Materials: The following are available online at https://www.mdpi.com/2223-774 7/10/1/124/s1, Figure S1: Enlarged correlation-loading plot of GC-MS analysis of essential oils of different Astragalus species based on the identification of compounds shown in Table 1.

Author Contributions: H.A.G., identification of the volatile compounds, chemometric analysis, writing the whole manuscript; N.Z.M., isolation of the volatiles, writing and revising the manuscript, R.Z.M., collection of the plants and isolation of the volatile compounds, S.B. and T.R., performing and hosting the GC-MS analysis and revising the manuscript, G.Z., carrying out the biology testing, N.M.A.M. and M.L.A., supervising the study and revising the manuscript. All authors have read and agreed to the published version of the manuscript.

Funding: This research was funded by King Saud University Researchers Supporting Project number (RSP-2020/294), King Saud University, Riyadh, Saudi Arabia.

Acknowledgments: The authors would like to thank the King Saud University Researchers Supporting Project number (RSP-2020/294), King Saud University, Riyadh, Saudi Arabia. The author (N.Z.M.) thanks the Alexander von Humboldt Foundation for providing the opportunity to perform work in Germany.

Conflicts of Interest: The authors declare no conflict of interest.

\section{References}

1. Amiri, M.S.; Joharchi, M.R.; Nadaf, M.; Nasseh, Y. Ethnobotanical knowledge of Astragalus spp.: The world's largest genus of vascular plants. Avicenna J. Phytomed. 2020, 10, 128-142. [PubMed]

2. Khassanov, F. Lectotypifications in the genus Astragalus L. s.l. (Fabaceae) in the flora of Uzbekistan. Stapfia 2015, 103, 67-73.

3. Li, X.; Qu, L.; Dong, Y.; Han, L.; Liu, E.; Fang, S.; Zhang, Y.; Wang, T. A review of recent research progress on the Astragalus genus. Molecules 2014, 19, 18850-18880. [CrossRef] [PubMed]

4. Salehi, B.; Carneiro, J.N.P.; Rocha, J.E.; Coutinho, H.D.M.; Morais Braga, M.F.B.; Sharifi-Rad, J.; Semwal, P.; Painuli, S.; Moujir, L.M.; de Zarate Machado, V.; et al. Astragalus species: Insights on its chemical composition toward pharmacological applications. Phytother. Res. 2020. [CrossRef]

5. Yang, L.P.; Shen, J.G.; Xu, W.C.; Li, J.; Jiang, J.Q. Secondary Metabolites of the Genus Astragalus: Structure and Biological-Activity Update. Chem. Biodiver. 2013, 10, 1004-1054. [CrossRef]

6. Sun, W.; Shahrajabian, M.H.; Cheng, Q. Astragalus and Chrysanthemum for Sustainable Life; LAP LAMBERT Academic Publishing: Rīgā, Latvia, 2019.

7. Rezaee, M.B.; Jaimand, K.; Karimi, M. Chemical Constituents of the Essential Oil from Astragalus microcephalus Willd. J. Essent. Oil Res. 2006, 18, 84-85. [CrossRef]

8. Akhlaghi, H. Chemical Composition of the Essential Oil from Aerial Parts of Astragalus schahrudensis Bge. from Northeast of Iran. J. Essent. Oil Bear. Plants 2009, 12, 59-63. [CrossRef]

9. Akhlaghi, H.; Rustaiyan, A.; Larijani, K.; Shafaghat, A.; Masnabadi, N.; Masoudi, S. Chemical Composition of the Essential Oil from Flower, Stem and Leaves of Astragalus schahrudensis Bge. from Iran. J. Essent. Oil Res. 2007, 19, 269-270. [CrossRef]

10. Naghiloo, S.; Movafeghi, A.; Delazar, A.; Nazemiyeh, H.; Asnaashari, S.; Dadpour, M.R. Ontogenetic variation of volatiles and antioxidant activity in leaves of Astragalus compactus Lam. (Fabaceae). EXCLI J. 2012, 11, 436-443.

11. Movafeghi, A.; Delazar, A.; Amini, M.; Asnaashari, S.; Nazifi, E. Composition of volatile organic compounds in flowers of Astragalus sahendi. Nat. Prod. Res. 2010, 24, 1330-1336. [CrossRef]

12. Movafeghi, A.; Djozan, D.; Razeghi, J.A.; Baheri, T. Identification of volatile organic compounds in leaves, roots and gum of Astragalus compactus Lam. using solid phase microextraction followed by GC-MS analysis. Nat. Prod. Res. 2010, 24, 703-709. [CrossRef] [PubMed]

13. Teyeb, H.; Zouari, S.; Douki, W.; Najjar, M.F.; Neffati, M. Variation in volatiles of Astragalus gombiformis Pomel. Z. Naturforsch. C 2011, 66, 1-6. [CrossRef] [PubMed] 
14. Teyeb, H.; Zouari, S.; Douki, W.; Najjar, M.F.; Neffati, M. Essential Oils of Leaves, Flowers and Fruits of Astragalus gombiformis Pomel (Fabaceae). Acta Hortic. 2010, 853, 263-268. [CrossRef]

15. Iskender, N.; Kahriman, N.; Tosun, G.; Terzioğlu, S.; Alpay Karaoğlu, Ş.; Yayli, N. Chemical Composition and Antimicrobial Activity of the Essential Oils from the Aerial Parts of Astragalus hamzaoglui Extracted by Hydrodistillation and Microwave Distillation. Rec. Nat. Prod. 2013, 7, 177-183.

16. Li, J.K.; Li, F.; Xu, Y.; Yang, W.J.; Qu, L.L.; Xiang, Q.; Liu, C.; Li, D.P. Chemical Composition and Synergistic Antioxidant Activities of Essential Oils from Atractylodes macrocephala and Astragalus membranaceus. Nat. Prod. Commun. 2013, 8, 1321-1324. [CrossRef]

17. Gecibesler, I.H.; Behcet, L.; Erdogan, M.K.; Askin, H. Antioxidant potencies and chemical compositions of essential oils of two endemic species grow in Turkey: Astragalus oocephalus subsp stachyophorus and Astragalus sericans. Prog. Nutr. 2017, 19, 60-67. [CrossRef]

18. Ghasemian-Yadegari, J.; Nazemiyeh, H.; Asnaashari, S.; Fathiazad, F. Chemical Characterization of the Essential Oil from Aerial Parts of Astragalus maximus from Northwest of Iran. Adv. Biosci. Clin. Med. 2015, 3, 32-39.

19. Sahin Yaglioglu, A.; Temirturk, M.; Ugur, E.; Dolarslan, M.; Demirtas, I. Metabolomics of endemic six Astragalus species by combined NMR and GC-MS analysis. Phytochem. Anal. 2020, 31, 306-313. [CrossRef]

20. El Bishbishy, M.H.; Gad, H.A.; Aborehab, N.M. Chemometric discrimination of three Pistacia species via their metabolic profiling and their possible in vitro effects on memory functions. J. Pharm. Biomed. Anal. 2020, 177, 112840. [CrossRef]

21. Gad, H.A.; El-Ahmady, S.H.; Abou-Shoer, M.I.; Al-Azizi, M.M. Application of Chemometrics in Authentication of Herbal Medicines: A Review. Phytochem. Anal. 2012, 24, 1-24. [CrossRef]

22. Ghahari, S.; Alinezhad, H.; Nematzadeh, G.A.; Tajbakhsh, M.; Baharfar, R. Phytochemical, Antioxidant and Biological Activities of the Essential Oil of Astragalus alopecurus Pall. Fruits from Northern Iran. J. Essent. Oil Bear. Plants 2018, 21, 103-115. [CrossRef]

23. López, M.D.; Pascual-Villalobos, M.J. Mode of inhibition of acetylcholinesterase by monoterpenoids and implications for pest control. Ind. Crops Prod. 2010, 31, 284-288. [CrossRef]

24. Miyazawa, M.; Yamafuji, C. Inhibition of acetylcholinesterase activity by bicyclic monoterpenoids. J. Agric. Food Chem. 2005, 53, 1765-1768. [CrossRef] [PubMed]

25. Bonesi, M.; Menichini, F.; Tundis, R.; Loizzo, M.R.; Conforti, F.; Passalacqua, N.G.; Statti, G.A.; Menichini, F. Acetylcholinesterase and butyrylcholinesterase inhibitory activity of Pinus species essential oils and their constituents. J. Enzyme Inhib. Med. Chem. 2010, 25, 622-628. [CrossRef] [PubMed]

26. Wojtunik-Kulesza, K.A.; Targowska-Duda, K.; Klimek, K.; Ginalska, G.; Jóźwiak, K.; Waksmundzka-Hajnos, M.; Cieśla, Ł. Volatile terpenoids as potential drug leads in Alzheimer's disease. Open Chem. 2017, 15, 332-343. [CrossRef]

27. Sarikurkcu, C.; Zengin, G. Polyphenol Profile and Biological Activity Comparisons of Different Parts of Astragalus macrocephalus subsp. finitimus from Turkey. Biology 2020, 9. [CrossRef]

28. Sekeroglu, N.; Gezici, S. Astragalus neurocarpus Bioss. as a potential source of natural enzyme inhibitor associated with Alzheime' s and Parkinson diseases along with its rich polyphenolic content and antioxidant activities. Ann. Phytomed. 2019, 8, 82-87. [CrossRef]

29. Santoro, V.; Parisi, V.; D’Ambola, M.; Sinisgalli, C.; Monné, M.; Milella, L.; Russo, R.; Severino, L.; Braca, A.; Tommasi, N.D. Chemical Profiling of Astragalus membranaceus Roots (Fish.) Bunge Herbal Preparation and Evaluation of Its Bioactivity. Nat. Prod. Commun. 2020, 15, 1934578X20924152. [CrossRef]

30. Youssef, F.S.; Mamatkhanova, M.A.; Mamadalieva, N.Z.; Zengin, G.; Aripova, S.F.; Alshammari, E.; Ashour, M.L. Chemical Profiling and Discrimination of Essential Oils from Six Ferula Species Using GC Analyses Coupled with Chemometrics and Evaluation of Their Antioxidant and Enzyme Inhibitory Potential. Antibiotics 2020, 9. [CrossRef]

31. Mamadalieva, N.Z.; Abdullaeva, N.S.; Rosenau, T.; Fakhrutdinova, M.; Azimova, S.S.; Bohmdorfer, S. Composition of essential oils from four Apiaceae and Asteraceae species growing in Uzbekistan. Nat. Prod. Res. 2018, 32, 1118-1122. [CrossRef]

32. Brereton, R.G. Applied Chemometrics for Scientists; John Wiley \& Sons: Chichester, UK, 2007; p. 379.

33. Mamadalieva, N.Z.; Böhmdorfer, S.; Zengin, G.; Bacher, M.; Potthast, A.; Akramov, D.K.; Janibekov, A.; Rosenau, T. Phytochemical and biological activities of Silene viridiflora extractives. Development and validation of a HPTLC method for quantification of 20-hydroxyecdysone. Ind. Crops Prod. 2019, 129, 542-548. [CrossRef]

34. Zengin, G.; Aktumsek, A. Investigation of antioxidant potentials of solvent extracts from different anatomical parts of Asphodeline anatolica E. Tuzlaci: An endemic plant to Turkey. Afr. J. Tradit. Complement. Altern. Med. 2014, 11, 481-488. [CrossRef] [PubMed]

35. Zengin, G. A study on in vitro enzyme inhibitory properties of Asphodeline anatolica: New sources of natural inhibitors for public health problems. Ind. Crops Prod. 2016, 83, 39-43. [CrossRef] 